\title{
EMERGENCE, INITIAL GROWTH AND PHOTOSYNTHETIC METABOLISM OF Ormosia arborea (Vell.) Harms UNDER DIFFERENT LIGHT AVAILABILITIES
}

\author{
Vanessa de Mauro Barbosa Freitas ${ }^{1 *}$, Silvana de Paula Quintão Scalon², Daiane Mugnol Dresch ${ }^{3}$, Sara da Silva \\ Bastos $^{4}$, Ana Paula Rissato de Souza ${ }^{5}$ e Fernanda Soares Junglos ${ }^{6}$ \\ ${ }^{1 *}$ Federal University of Grande Dourados, Faculty of Agrarian Sciences, Graduate program of Agronomy and Plant Production, Dourados, \\ Mato Grosso do Sul, Brazil - vanessamauro@yahoo.com.br \\ ${ }^{2}$ Federal University of Grande Dourados, Teacher of the Faculty of Agrarian Sciences, Dourados, Mato Grosso do Sul, Brazil - \\ silvanascalon@ufgd.edu.br \\ ${ }^{3}$ Federal University of Grande Dourados, Faculty of Agrarian Sciences, Graduate program of Agronomy and Plant Production, Dourados, \\ Mato Grosso do Sul, Brazil - daiamugnol@ hotmail.com, sarinhaiibastos@hotmail.com, paulinharissato@hotmail.com, \\ fernandajunglos@yahoo.com.br.
}

Received for publication: 21/03/2018 - Accepted for publication: 19/06/2020

\section{Resumo}

Emergência, crescimento inicial e metabolismo fotossintético de Ormosia arborea (Vell.) Harms sob diferentes disponibilidades luminosas. A recomposição de ecossistemas alterados e degradados somente terá sucesso se pesquisas gerarem conhecimentos biológicos, ecológicos e fisiológicos sobre as espécies de diversos ecossistemas brasileiros. Para a produção de mudas de qualidade é fundamental o conhecimento ecofisiológico da fase inicial das espécies, pois o sombreamento artificial pode interferir na taxa de crescimento e qualidade da muda. Objetivou-se neste estudo avaliar o efeito de diferentes níveis de sombreamento na emergência, crescimento inicial e metabolismo fotossintético de Ormosia arborea. O experimento foi realizado sob sombreamento de $30 \%$ e $70 \%$ e a pleno sol. Aos 60 dias após a semeadura, foram realizadas análises não destrutivas (trocas gasosas e fluorescência da clorofila) e destrutivas (medidas de crescimento). O sombreamento de $70 \%$ proporciona maior emergência, crescimento inicial, trocas gasosas e eficiência fotossintética do PS II. O cultivo a $0 \%$ de sombreamento (pleno sol) não é indicado para esta espécie.

Palavras-chave: produção de mudas, sombreamento, trocas gasosas

\begin{abstract}
The restoration of altered and degraded ecosystems will only be successful if research studies generate biological, ecological and physiological knowledge about the species of different Brazilian ecosystems. In order to produce quality seedlings, ecophysiological knowledge of the initial phase of the species is essential, since artificial shading can interfere with the growth rate and quality of the seedling. The aim of this study was to assess the effect of different levels of shading on the emergence, initial growth and photosynthetic metabolism of Ormosia arborea. The experiment was carried out with $30 \%$ and $70 \%$ shade and in full sun. At 60 days after sowing, non-destructive (gas exchange and chlorophyll fluorescence) and destructive (growth measures) analyzes were performed. $70 \%$ shade provides greater emergence, initial growth, gas exchange and photosynthetic efficiency of PS II. Cultivation at $0 \%$ shade (full sun) is not suitable for this species.

Keywords: seedling production, shade, gas exchange
\end{abstract}

\section{INTRODUCTION}

The success of restoration and planting projects for sustainable exploitation depends on biological, ecological and physiological knowledge of species from different Brazilian ecosystems with potential for use in degraded environments. Therefore, several programs have been established in order to recover these environments (SANTOS et al., 2012), either through direct sowing or through planting seedlings.

To produce quality seedlings, ecophysiological knowledge of the initial phase of the species is essential (SOUZA et al., 2013) and artificial shading can have a positive effect on the growth rate and quality of the seedling, and the responses vary according to ecological class (SIEBENEICHLER et al., 2008; SOUZA et al., 2013; REIS et al., 2016).

FLORESTA, Curitiba, PR, v. 50, n. 4, p. 1689 - 1697, out/dez 2020.

Freitas, V. M. B. et.al. 
The ability of seedlings to grow quickly when shaded is an important mechanism for adapting the species and constitutes a valuable strategy to survive in low light intensity environments (SIEBENEICHLER et al., 2008). Most plants develop mechanisms to adjust to the environments in which they live, especially with regards to temperature and light changes (SEARLE et al., 2011). Some of these mechanisms are the regulation of stomatal conductance (AASAMAA; SÕBER, 2011) and the adjustment of the photosynthetic apparatus so as to enable adequate absorption, transfer and use of available electromagnetic energy (GONÇALVES et al., 2010).

Ormosia arborea (Vell.) Harms (Fabaceae: Papilionoideae), popularly known as goat's eye, is a tree species native to the Atlantic Forest and the Cerrado classified as late secondary or climax (CARVALHO, 2008), which can be found in the Gallery Forests of the Cerrado (SANO et al., 2008).

Considering the successional classification of $O$. arborea, it is believed that its seeds do not tolerate high light availability without satisfactorily expressing its vigor and that its seedlings have low photosynthetic activity when grown at $0 \%$ shade. Thus, our aim was to assess the effect of different levels of shade on the emergence, initial growth and photosynthetic metabolism of $O$. arborea seedlings.

\section{MATERIALS AND METHODS}

The emergence experiment was carried out under protected cultivation at the Faculty of Agricultural Sciences of the Federal University of Grande Dourados from October to December 2016. The experiment was carried out in 5-liter polyethylene pots containing dystrophic Red Latosol and sand in the proportion of 1:1 (v/v). The pots were exposed to three different light availabilities: $0 \%$ (full sun - no sun mesh shade); $30 \%$ and $70 \%$ shade. Such light exposure was accomplished with the help of a Sombrite ${ }^{\circledR}$ black nylon mesh and daily irrigation at a $70 \%$ water retention capacity (WRC) of the substrate. The luminous intensity was determined using a Digital Luxmeter (ICEL LD-510) that registered 85,000 Lux at 0\% shade.

For each light setting, we used twenty pots with five seeds each, totaling 100 seeds. 40 days after emergence, we assessed the percentage of emergence (\%), emergence speed index (ESI) (MAGUIRE, 1962) and mean emergence time (days) (RANAL; SANTANA, 2006).

At the end of the emergence experiment, we thinned the pots so that only two seedlings remained in each pot. 60 days after sowing, analyses of the leaf water potential, gas exchange, chlorophyll $a$ fluorescence and seedling growth were performed.

Leaf water potential $\left(\Psi_{\mathrm{w}}-\mathrm{MPa}\right)$ was registered with the aid of a pressure chamber (Portable Plant water status console - 3115 model) between 10 and $11 \mathrm{am}$, using individual fully expanded leaves, immediately after leaf collection.

Gas exchange measurements were performed using the LCIPro-SD ADC BioScientific Ltd. portable photosynthesis meter. The following parameters were assessed: $A$ : photosynthetic rate $\left(\mu \mathrm{mol} \mathrm{m} \mathrm{m}^{-2} \mathrm{~s}^{-1}\right), g s$ : stomatal conductance $\left(\mathrm{mol} \mathrm{m} \mathrm{m}^{-2}\right), E$ : transpiration $\left(\mathrm{mmol} \mathrm{m}^{2} \mathrm{~s}^{-1}\right)$ and $C i$ : intercellular $\mathrm{CO}_{2}$ concentration $(\mu \mathrm{mol}$ $\left.\mathrm{mol}^{-1}\right)$. Rubisco's carboxylation efficiency $(A / C i)$ and water use efficiency $(A / E)$ were calculated using the values of $A, C i$ and $E$.

As for the measures of chlorophyll $a$ fluorescence, we assessed the initial fluorescence (F0), maximum fluorescence (Fm) and the potential quantum efficiency of photosystem II (Fv/Fm). The fluorescence data was then used to calculate the effective absorbed energy conversion efficiency (Fv/F0) and the basal quantum production of non-photochemical processes in photosystem II (F0/Fm). The measurements were made on the seedlings' first pair of leaves counting from the apex, which were completely expanded by means of a portable fluorometer OS-30p model (Opti-Sciences Chlorophyll Fluorometer, Hudson, USA). We adopted the saturation pulse method. The leaves were pre-adapted to the dark with the aid of adapter clips, so that all reaction centers in this leaf region remained of "open", i.e., until their photosynthetic electron transport system was in a state of complete oxidation. The measurements of chlorophyll $a$ fluorescence and gas exchange were carried out between 8 and $11 \mathrm{am}$, on the same leaves used for gas exchange assessments.

To assess growth, root and shoot lengths were measured using a graduated ruler, with results expressed in centimeters (cm); leaf area was measured with the aid of the Li 3100 - Area Meter $\left(\mathrm{cm}^{2}\right)$; fresh mass of leaf, stem and root were obtained by weighting each organ using a precision analytical balance $(0.0001 \mathrm{~g})$, with results expressed in grams $(\mathrm{g})$; dry mass of leaf, stem and root were obtained by drying each organ in a forced convection oven at $70^{\circ} \mathrm{C}$ for 72 hours or until they reached constant mass, then weighting them on a precision analytical balance $(0.0001 \mathrm{~g})$, with results expressed in grams $(\mathrm{g})$; stem diameter was measured with the aid of a Digimess digital caliper $(0.001 \mathrm{~mm})$, with results expressed in millimeters $(\mathrm{mm})$. The SPAD index (Soil Plant

FLORESTA, Curitiba, PR, v. 50, n. 4, p. 1689 - 1697, out/dez 2020.

Freitas, V. M. B. et.al.

ISSN eletrônico 1982-4688

1690

DOI: $10.5380 /$ rf.v50 i4. 58541 
Analysis Development) was assessed using a portable chlorophyll meter, Konica Minolta, SPAD-502 model, and the readings were made in the middle lobes of the first pair of completely expanded leaves of the seedlings, counted from the apex. To assess seedlings' quality, Dickson's Quality Index (DICKSON et al., 1960) was calculated based on the following equation: DQI $=$ TDM/[(H/D)+(DMAP/DMR)], where DMT = dry mass total $($ leaf + stem + root $)$ and DMAP $=$ dry mass aereal part $($ leaf + stem $)$.

The experiment was carried out in a completely randomized design and the data were submitted to analysis of variance (ANOVA) and, when significant, the means were compared by Tukey's test (1\% and 5\%), using the statistical program SISVAR 5.6 (FERREIRA, 2014).

The maximum and minimum temperatures $\left({ }^{\circ} \mathrm{C}\right)$ and maximum and minimum relative air humidity (RH\%) registered during the experiment period are shown in Figure 1. The data were obtained from the Embrapa Climate Guide database.

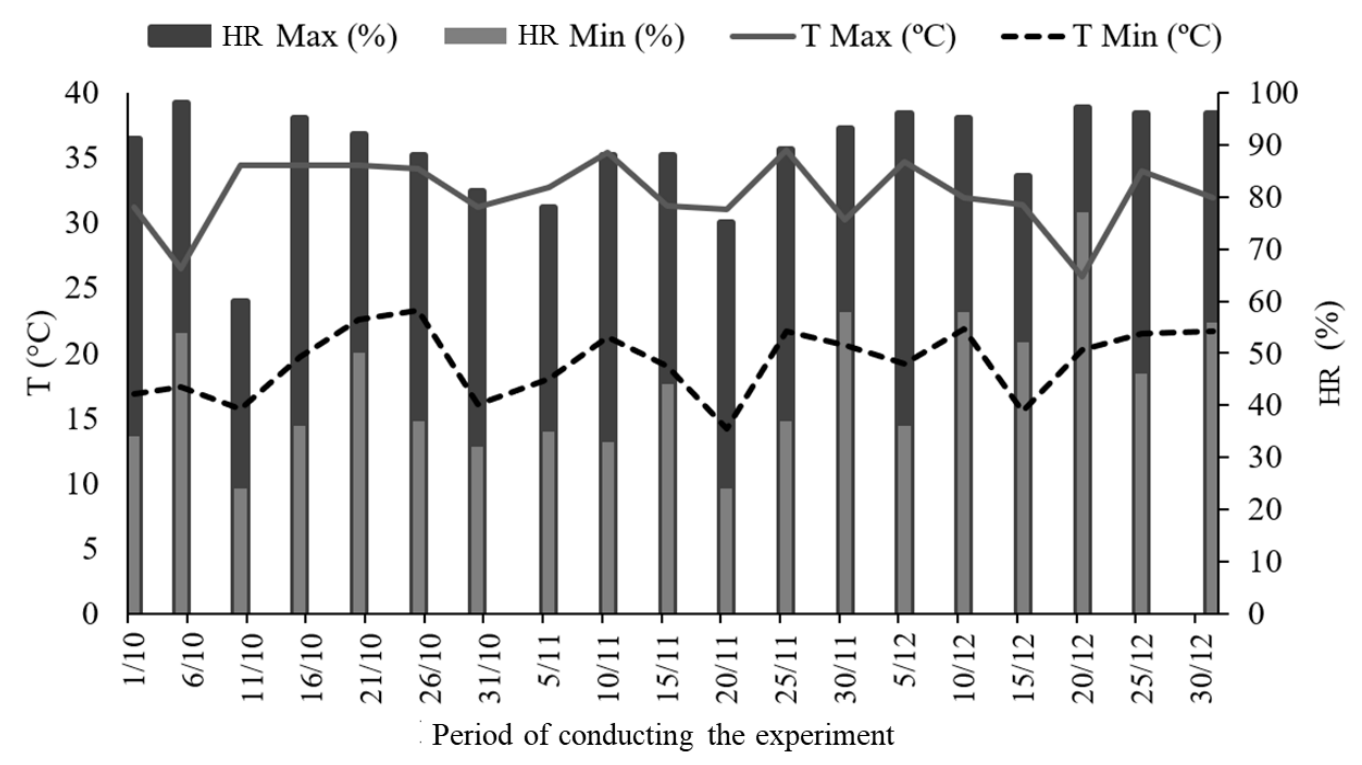

Figure 1. Maximum temperature ( $\mathrm{T}$ Max) and minimum ( $\mathrm{T}$ Min), relative humidity (RH Max) and minimum (RH Min ) observed during the period of conducting the experiment (01/10 to 31/12).

Figura 1. Temperatura máxima (TMax) e mínima (TMin), umidade relativa do ar máxima (UR Max) e mínima (UR Min) observadas durante o período de condução do experimento (01/10 a 31/12).

\section{RESULTS}

The percentage of emergence of Ormosia arborea was the highest when sowing occurred under $30 \%$ shade $(77 \%)$, followed by $70 \%$ shade $(59 \%)$ and $0 \%$ shade (10\%) (Figure 2A). The emergence speed index (ESI) was the highest when under $70 \%$ shade (Figure $2 \mathrm{~B}$ ), which was not significantly different from when sowing occurred under $30 \%$ shade. As for the average emergence time (Figure 2C), cultivation under 30\% shade resulted in the shortest emergence time (13.25 days), followed by $70 \%$ shade (19.01 days), while $0 \%$ shade delayed the emergence, which happened only at 39.8 days. 

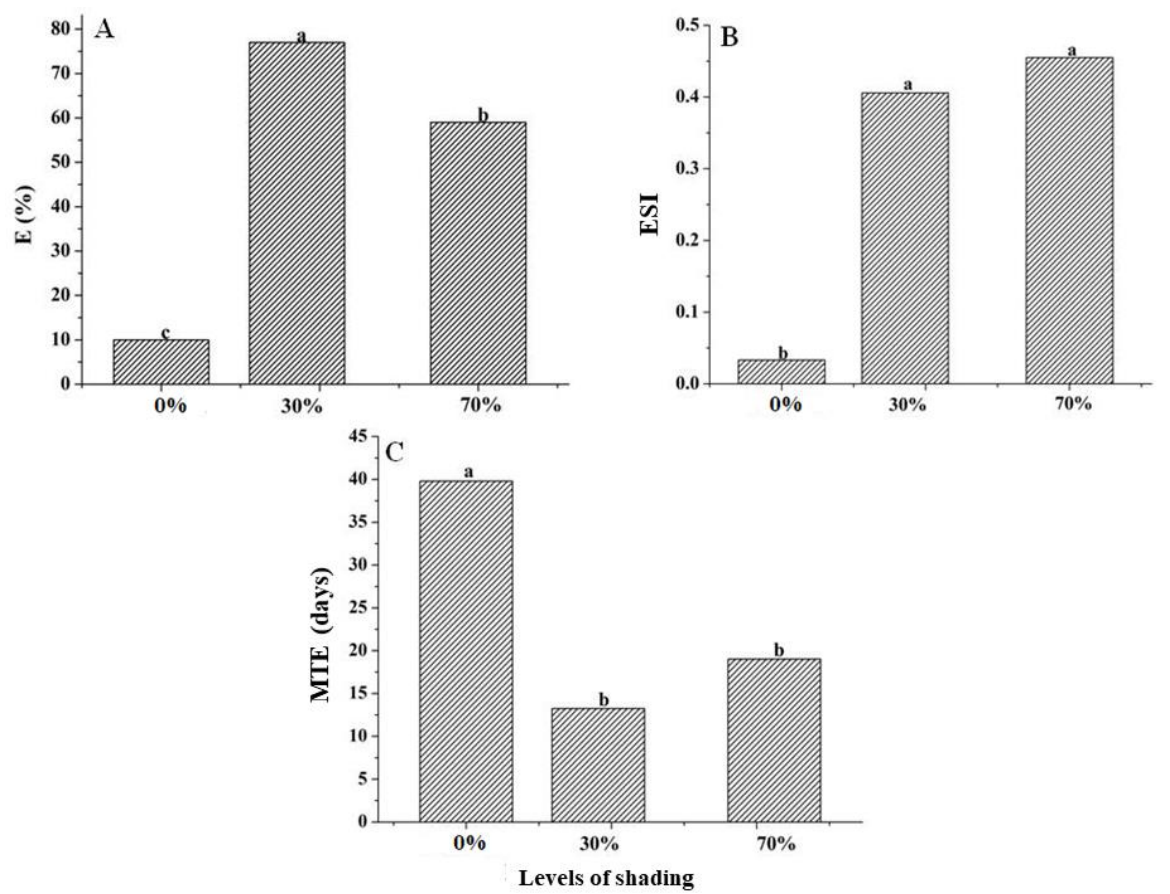

Figure 2. Percentage of emergency - E (\%) (A), emergency speed index - ESI (B) and mean time of emergency - MTE (C) of seedlings of Ormosia arborea submitted different levels of shading.

Figura 2. Porcentagem de emergência - E (\%) (A), índice de velocidade de emergência - IVE (B) e tempo médio de emergência - TME (C) de plântulas de Ormosia arborea submetidas a diferentes níveis de sombreamento.

The leaf water potential $(\Psi \mathrm{w})$ was more negative in plants cultivated under $0 \%$ shade (Figure $3 \mathrm{~A})$. We observed the highest photosynthetic $(A)$ and transpiratory $(E)$ rates in plants under $70 \%$ shade (Figure $3 \mathrm{~B}$ and 3C). Values of water use efficiency (WUE) were not significantly different between seedlings subjected to $30 \%$ and $70 \%$ shade (Figure 3D).
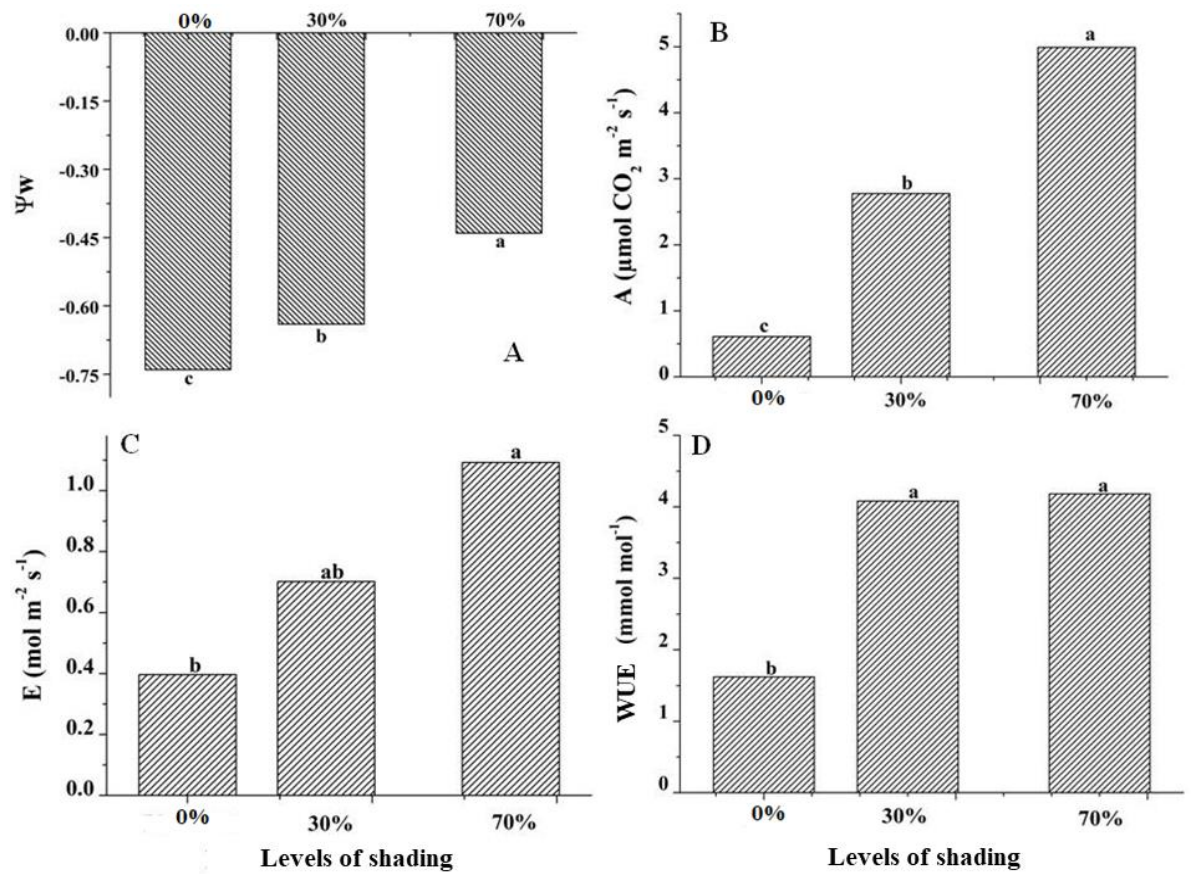

FLORESTA, Curitiba, PR, v. 50, n. 4, p. 1689 - 1697, out/dez 2020. 
Figure 3. Leaf water potential - $\Psi_{\mathrm{W}}(\mathrm{A})$, Photosynthesis $-A(\mathrm{~B})$, Transpiration $-E(\mathrm{C})$ and Water-use efficiency

- WUE (D) of seedlings of Ormosia arborea submitted different levels of shading.

Figura 3. Potencial hídrico foliar - $\Psi_{\mathrm{W}}(\mathrm{A})$, Fotossíntese - $A(\mathrm{~B})$, transpiração - $E(\mathrm{C})$ e eficiência no uso da água - EUA (D) de plantas de Ormosia arborea submetidas a diferentes níveis de sombreamento.

Stomatal conductance $(g s)$ was also lower in seedlings exposed to $0 \%$ shade (Figure 4A), along with reduced photosynthesis. Cultivation at $0 \%$ shade resulted in the highest values of inner $\mathrm{CO}_{2}$ concentration $(\mathrm{Ci})$ (Figure 4B). The increase in intercellular $\mathrm{CO}_{2}$ concentration relates to the lower carboxylation efficiency of the rubisco enzyme under these circumstances and its higher efficiency when under 70\% shade (Figure 4C). Thus, under $70 \%$ shade, the plants showed higher stomatal conductance and greater assimilation of the substrate for the rubisco enzyme, with a higher photosynthesis rate.

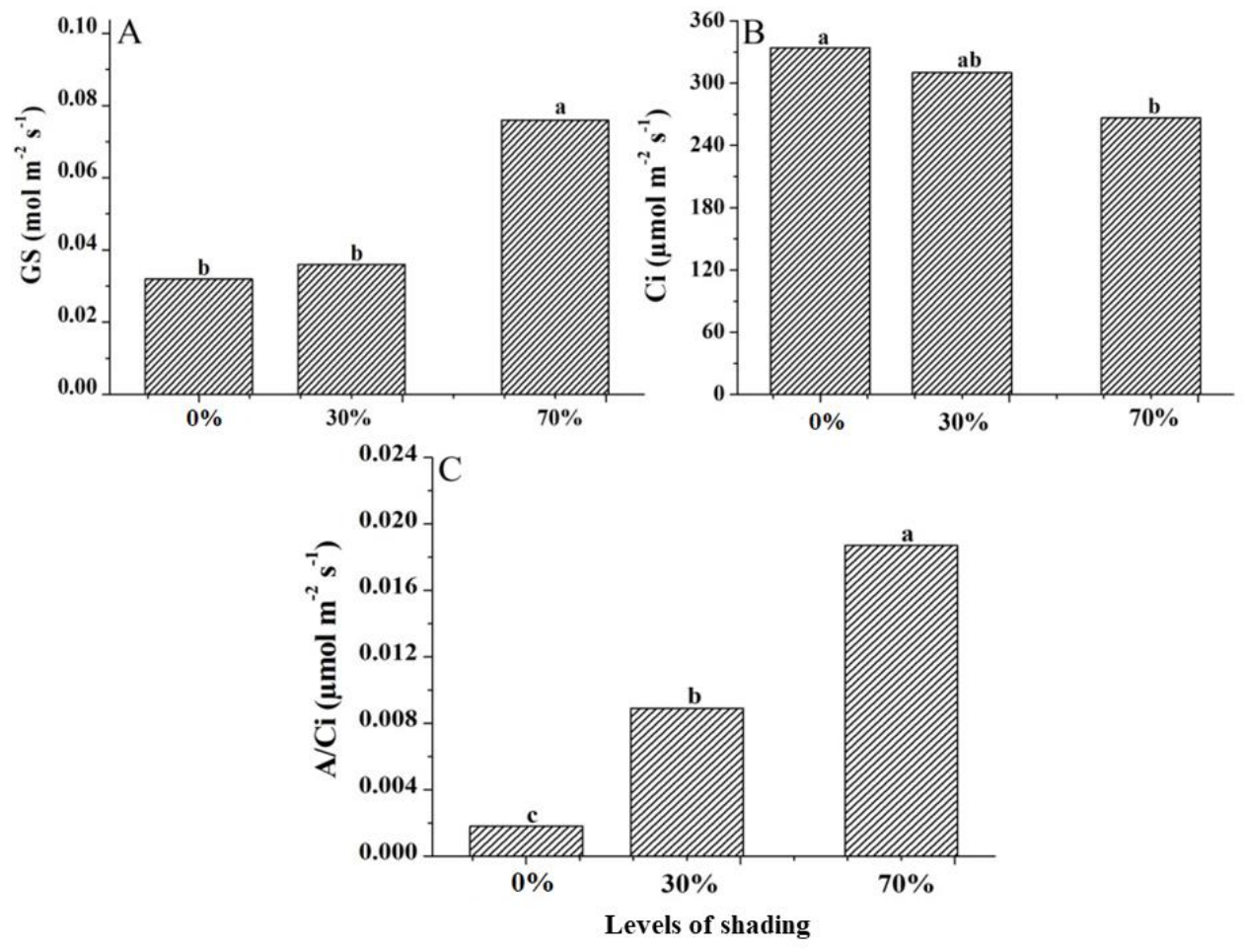

Figure 4. Stomatal conductance - $g s(\mathrm{~A})$, internal $\mathrm{CO}_{2}$ concentration $-\mathrm{Ci}$ (B) and carboxylation efficiency A/Ci (C) of seedlings of Ormosia arborea submitted different levels of shading.

Figura 4. Condutância estomática - $g s(\mathrm{~A})$, concentração interna de $\mathrm{CO}_{2}-C i(\mathrm{~B})$ e eficiência de carboxilação A/Ci (C) de mudas de Ormosia arborea submetidas a diferentes níveis de sombreamento.

The quantum efficiency of the photochemical activity of PSII (Fv/Fm) was higher in plants under $30 \%$ shade (Figure 5A). The effective absorbed energy conversion efficiency in PSII (Fv/F0) had lower values in plants grown at $0 \%$ and $30 \%$ shade (Figure 5B) which stayed below the range of 4 to 6 quantum $^{-1}$ electrons. The basal quantum production of non-photochemical processes in PSII (F0/Fm) was higher in plants grown at $0 \%$ shade, with an average of 0.45 (Figure 5C). 

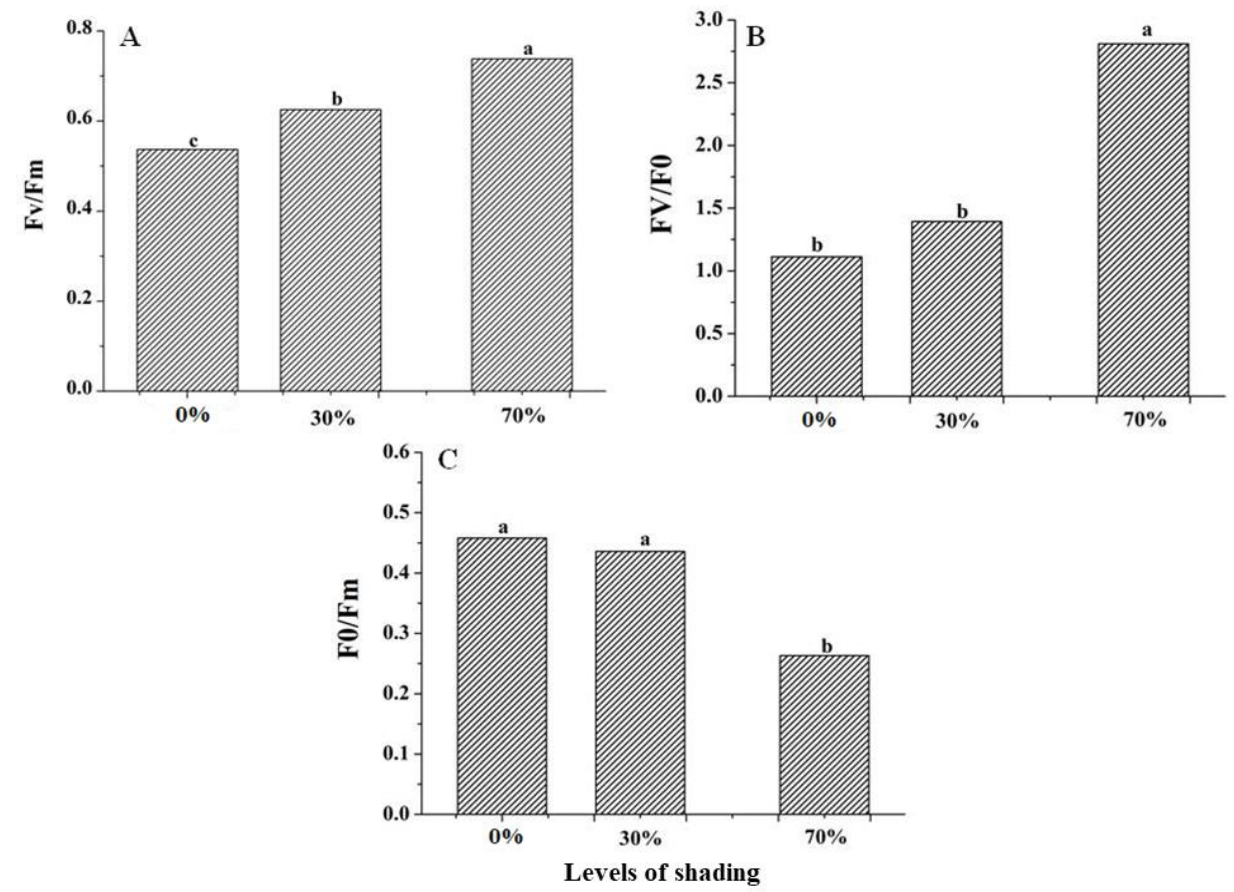

Figure 5. Quantum efficiency of the photosystem II - Fv/Fm (A), Effective efficiency of conversion of energy absorbed the photosystem - Fv/F0 (B) and Basal quantum production of non-photochemical processes in photosystem II - F0/Fm (C) of seedlings of Ormosia arborea submitted different levels of shading.

Figura 5. Eficiência quântica do fotossistema II - Fv/Fm (A), Eficiência efetiva da conversão de energia absorvida pelo fotossistema - Fv/F0 (B) e Produção quântica basal dos processos não fotoquímicos no fotossistema II - F0/Fm (C) de mudas de Ormosia arborea submetidas a diferentes níveis de sombreamento.

Leaf area, chlorophyll index and DQI were higher in seedlings grown at $70 \%$ shade and decreased as light availability increased (Figure 6A, 6B and 6C).

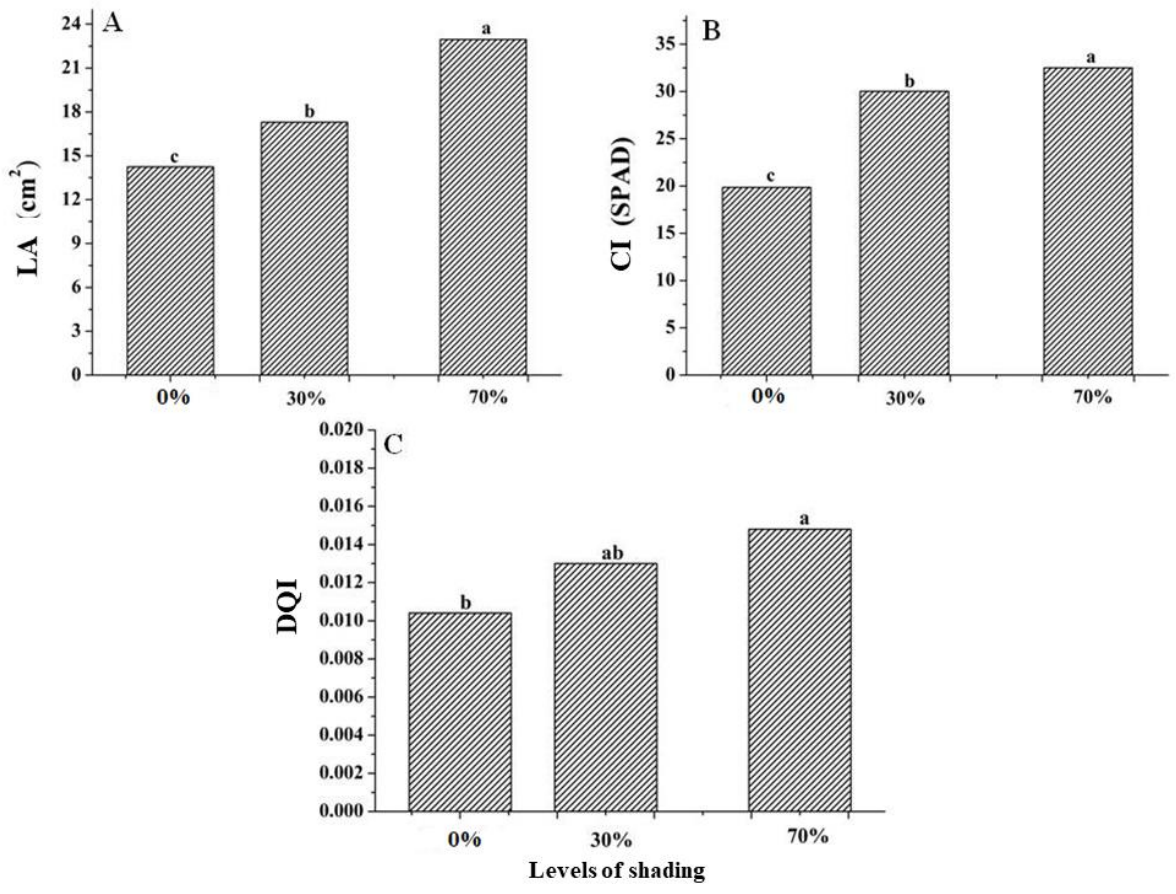

FLORESTA, Curitiba, PR, v. 50, n. 4, p. 1689 - 1697, out/dez 2020. 
Figure 6. Leaf area - LA (A), Chlorophyll Index - CI (B) and Dickson Quality Index - DQI (C) of seedlings of Ormosia arborea submitted different levels of shading.

Figura 6. Área foliar - AF (A), índice de clorofila - IC (B) e Índice de Qualidade de Dickson - IQD (C) de mudas de Ormosia arborea submetidas a diferentes níveis de sombreamento.

\section{DISCUSSION}

The results of emergence, growth, gas exchange, photosynthetic efficiency of PS II and quality of seedlings observed in cultivation under shading corroborate information from the literature that $O$. arborea is a species that occurs in Dense Ombrophylous Forest (CARDOSO; MEIRELES, 2015), and does not tolerate to be cultivated at $0 \%$ shade (full sun).

The lower percentages and speed of emergence and the high average time of emergence at $0 \%$ shade can be attributed to the fact that exposure to high solar radiation stresses the seeds due to the higher temperature in the substrate and less stable water availability caused by a greater evaporation rate, thus hindering the seed imbibition process, as suggested by Scalon et al. (2014), who observed that seeds of Stryphnodendron polyphyllum (Mart.) and S. adstringens (Mart. Coville) were also sensitive to the increase in light intensity.

The conditions under which they were cultivated had an impact not only on the vigor of the seeds but also on seedlings' growth, metabolism and quality. The environment at $0 \%$ shade may have become stressful to $O$. arborea seedlings due to the high temperatures at the time of the experiment (Figure 1). When hydrated, in general, plants tend to have a water potential close to zero. As such, the most hydrated seedlings were those under $70 \%$ of shade, since shaded spots tend to be more humid, as the substrate surface suffers less from evaporation, which keeps the stomata open for longer, thus favoring greater $\mathrm{CO}_{2}$ assimilation and photosynthetic rate.

The leaf water potential describes its energetic state, and determines the flows of water in the soil-plantatmosphere system, such that cell growth, photosynthesis and productivity are influenced by the water potential (TAIZ; ZEIGER, 2013). This behavior explains the higher rates of photosynthesis, transpiration, stomatal conductance, water use efficiency and carboxylation of the Rubisco enzyme efficiency when under shade.

The WUE of a given species expresses its effectiveness in fixing carbon as it transpires. Most of the water absorbed by the roots is evaporated from the leaf surfaces by transpiration, while a small part remains in the plant to meet the demands of growth, photosynthesis and other metabolic processes (MAHOUACHI, 2009; TAIZ; ZEIGER, 2013).

The stomatal response relates to the water dynamics of the plant, as a strategy to conserve water resources. Other studies also report lower values of stomatal conductance in high temperature conditions (as is normally observed in cultivation at $0 \%$ shade), which results in greater water conservation and photoprotection, despite the lower instantaneous carbon gain (DIAS; MARENCO, 2007).

Potential quantum efficiency in photosystem II values $(\mathrm{Fv} / \mathrm{Em})$ below 0.75 in seedlings grown in full sun may indicate stress, as the reference values range from 0.75 to 0.80 for other species (BAKER; ROSENQVST, 2004). Values far below this range suggest that low photosynthesis rates are also linked to damage to the photosynthetic apparatus, and are not exclusively linked to stomatal conductance and to the amount of internal carbon. Thus, according to the afore mentioned authors, a decrease in this ratio reflects the presence of photoinhibitory damage in the reaction centers of the PSII.

Because the reference value for effective absorbed energy conversion efficiency (Fv/F0) in plants is between 4 and 6 (ZANANDREA et al., 2006) and the value for basal quantum production of non-photochemical processes is between 0.14 and 0.20 (ROHÁCEK, 2002), values of Fv/F0 below 4 or excessively high values of F0/Fm indicate stress. In this study, we observed that $O$. arborea seedlings had average values of Fv/F0 and F0/Fm that could be considered signs of stress under all of the assessed cultivation conditions. However, the development stage at which the species is being assessed must be considered, since all other metabolic and growth characteristics were deemed satisfactory under shaded cultivation.

Chlorophyll $a$ fluorescence is a tool that has been used to measure the photosynthetic efficiency of the photosystem II (PSII). Although Kaiser et al. (2016) suggested that the activity of photosystems in conditions of low light intensity may not be complete, which would compromise photochemical efficiency and the production of ATP and NADPH that are used for fixing $\mathrm{CO}_{2}$ in biochemical processes, as well as lead to low photosynthetic rates, this response pattern was only observed in $O$. arborea seedlings grown under full sunlight exposure.

FLORESTA, Curitiba, PR, v. 50, n. 4, p. 1689 - 1697, out/dez 2020.

Freitas, V. M. B. et.al.

ISSN eletrônico 1982-4688 
Another explanation for seedlings' response under full sunlight would be that their exposure to high temperatures during the experiment may have inhibited the assimilation of $\mathrm{CO}_{2}$ by reducing the Rubisco activation state via inhibition of Rubisco activase, stomatal closure and decrease of the photochemical activity of photosynthesis (SILVA et al., 2015).

Where the values of leaf area and chlorophyll were the highest, the photosynthetic rate was also the highest in the same cultivation condition. Therefore, the decrease of growth characteristics under full sun may have happened due to the decrease in the production of photoassimilates, evidenced by the low rates of photosynthesis. Mota et al. (2012) observed in their review that in leaves of plants that develop under low light intensity, chlorophyll concentration tends to be higher than in leaves that grow under full sunlight, with a similarly increased leaf area and height. These responses act as mechanisms to maximize photon capture efficiency, thus increasing photosynthetic efficiency. Such behavior was observed in $O$. arborea in this study and elsewhere in Populus deltoids (RODRIGUEZ et al., 2015). Copaifera langsdorffii seedlings exhibited good growth plasticity under full sun and also under 30, 50, 70 and 90\% shade, although they displayed better development and quality (DQI) at 50\% shade (REIS et al., 2016).

It is worth noting that the greater development of the aerial part of the seedlings and their greater quality and capacity to carry out photosynthetic metabolism under shade can ensure greater competitive advantage to the species when settling in clearings or environments with medium levels of disturbance, as well as in more advanced cultivation phases when recovering degraded forests. Thus, we recommend producing seedlings of this species under $70 \%$ shade, in order to ensure higher seedling quality and possibly better field survival.

\section{CONCLUSION}

- $\quad 70 \%$ shade is the most suitable for the emergence of $O$. arborea.

- Seedlings show greater initial growth, gas exchange, photosynthetic efficiency of PS II and quality when grown under $70 \%$ shade, and cultivation under full sun is not suitable for this species.

\section{REFERENCES}

AASAMA, K.; SÕBER, A. Stomatal sensitivities to changes in leaf water potential, air humidity, CO2 concentration and light intensity, and the effect of abscisic acid on the sensitivities in six temperature deciduous tree species. Environmental and Experimental Botany, Oxford, v. 71, p. 72-78, 2011.

BAKER, N. R.; ROSENQVST, E. Applications of chlorophyll fluorescence can improve crop production strategies: an examination of future possibilities. Journal of Experimental Botany, Oxford, v. 55, p. 1607 $1621,2004$.

CARDOSO, D. B. O. S.; MEIRELES, J. E. 2015 Ormosia in Lista de Espécies da Flora do Brasil. Jardim Botânico do Rio de Janeiro. Disponível em: 〈http://floradobrasil.jbrj.gov.br/jabot/floradobrasil/FB29802〉.

DIAS, D. P.; MARENCO, R. A. Fotossíntese e fotoinibição em mogno e aquariquara em função da luminosidade e temperatura foliar. Pesquisa Agropecuária Brasileira, Brasília, v. 42, n. 3, p. 305-311, 2007.

DICKSON, A.; LEAF, A. L.; HOSNER, J. F. Quality appraisal of white spruce and white pine seedling stock in nurseries. Forest Chronicles, v. 36, n. 1, p. 10-13, 1960.

FERREIRA, D. F. Sisvar: a Guide for its Bootstrap procedures in multiple comparisons. Ciência e Agrotecnologia, Lavras, v. 38, n. 2 p. 109-112, 2014.

GONÇALVES, J. F. C., SILVA, C. E., GUIMARÃES, D. G., BERNARDES, R. S. Análise dos transientes da fluorescênciada clorofila a de plantas jovens de Carapa guianensis e de Dipteryx odorata sumetidas a dois ambientes de luz. Acta Amazônica, Manaus, v. 40, n. 1, p. 89-98, 2010.

KAISER, E.; MORALES, A.; HARBINSON, J.; HEUVELINK, E.; PRINZENBERG, A. E.; MARCELIS, L. F. Metabolic and diffusional limitations of photosynthesis in fluctuating irradiance in Arabidopsis thaliana. Scientific Reports. v. 6, 2016.

MAGUIRE, J. D. Speed of germination-aid in selection and evaluation for seedling emergence and vigor. Crop Science, Madison, v. 2, n. 1, p. 176-177, 1962. 
MAHOUACHI, J. Changes in nutrient concentrations and leaf gas exchange parameters in banana plantlets under gradual oil moisture depletion. Scientia Horticulturae, v. 120, p. 466-469, 2009.

MOTA, L. H.; SCALON. S. P. Q.; HEINZ, R. Sombreamento na emergência de plântulas e no crescimento inicial de Dipteryx alata Vog. Ciência Florestal, Santa Maria, v. 22, n. 3, p. 423-431, 2012.

MOURA, E. A.; CHAGAS, P. C.; MOURA, M. L. S.; SOUZA, O. M.; CHAGAS, E. A. Emergência e desenvolvimento inicial de plântulas de cupuaçu cultivadas sob diferentes substratos e condições de sombreamento. Revista Agroambiente On-line, v. 9, n. 4, p. 405-413, 2015.

RANAL, M. A.; SANTANA, D. G. How and why to measure the germination process?. Revista Brasileira de Botânica, São Paulo, v. 29, n. 1, p. 1-11, 2006.

REIS, S. M.; MARIMON-JÚNIOR, B. H.; MORANDI, P. S., SANTOS, C. O.; OLIVEIRA, B., MARIMON, B. S. Desenvolvimento inicial e qualidade de mudas de Copaifera langsdorffii Desf. sob diferentes níveis de sombreamento. Ciência Florestal, Santa Maria, v. 26, n. 1, p. 11-20, 2016.

RODRIGUEZ, M. E.; ACHINELLI1, F. G.; LUQUEZ, V. M. C. Leaf traits related toproductivity in Populus deltoids during the post-flooding period. Trees, v. 29, p. 953-960, 2015.

SANO, S. M.; ALMEIDA, S. P.; RIBEIRO, J. F. Cerrado Ecologia e Flora. V. 2, Embrapa Cerrados, Brasília, DF, 2008.

SANTOS, P. L.; FERREIRA, R. A.; ARAGÃO, A. G.; AMARAL, L. A.; OLIVEIRA, A. S. Estabelecimento de espécies florestais nativas por meio de semeadura dieta para recuperação de áreas degradadas. Revista Árvores, Viçosa, v.36, n. 2, p. 237-245, 2012.

SEARLE, S. Y., THOMAS, S., GRIFFIN, K. L., HORTON, T., KORNFELD, A., YAKIR, D., HURRY, V., TURNBULL, M. H. Leaf respiration and alternative oxidase in field-grown alpine grasses respond to natural changes in temperature and light. New phytologist, v. 189, p. 1027-1039, 2011.

SIEBENEICHLER, S. C.; FREITAS, G. A.; SILVA, R. R.; ADORIAN, G. C.; CAPELLARI, D. Características morfofisiológicas em plantas de Tabebuia heptaphyilla (vell.) tol. Em condições luminosidade. Acta Amazonica, Manaus, v. 38, n. 3, p. 467- 472, 2008.

SILVA, F. G.; DUTRA, W. F.; DUTRA, A. F.; OLIVEIRA, I. M.; FILGUEIRAS, L. M. B.; MELO, A. S. Trocas gasosas e fluorescência da clorofila em plantas de berinjela sob lâminas de irrigação. Revista Brasileira de Engenharia Agrícola e Ambiental, Campina Grande, v. 19, n. 10, p. 946-952, 2015.

SCALON, S. P. Q.; MASETTO, T. E.; MATOS, D. S. C.; MOTA, L. H. S. Condicionamento fisiológico e níveis de sombreamento em sementes de barbatimão (Stryphnodendron polyphyllum (Mart.) e S. adstringens (Mart.) Coville). Revista Árvore, Viçosa, v. 38, p. 145-153, 2014.

SOUZA, S. A.; ABREU, S. C.; SILVA, C. M.; SANTOS, J. X.; REIS, A. R. S. Desenvolvimento inicial de plântulas de tamboril [Enterolobium contortisiliquum (Vell.) Morong] em diferentes níveis de intensidade luminosa. Informativo ABRATES, Londrina, v. 23, n. 3, p. 32-36, 2013.

STIRBET, A.; GOVINDJE, E. On the relation between the Kautsky effect (chlorophyll a fluorescence induction) and Photosystem II: Basics and applications of the OJIP fluorescence transient. Journal of Photochemistry and Photobiology B: Biology, v.104, p. 236-257, 2011.

TAIZ, L; ZEIGER, E. Fisiologia vegetal. 5a edição. Editora Artmed, 2013. 918p.

ZANANDREA, I.; NASSI, F. L.; TURChETTO, A. C.; BRAGA, E. J. B.; PETERS, J. A.; BACARI, M. A. Efeito da salinidade sob parâmetros de fluorescência em Phaseolus vulgaris. Revista Brasileira de Agrociência, Pelotas, v. 12, n. 2, p. 157-161, 2006. 